\title{
Use of TCO Analysis in Industry 4.0
}

\author{
Miroslava Barbušová ${ }^{1}$, Iveta Medvecká ${ }^{1}$, Martin Gašo ${ }^{1}$ \\ ${ }_{1}$ University of Žilina, Faculty of Mechanical Engineering, Department of Industrial \\ Engineering \\ Univerzitná 1, 01026 Žilina, Slovakia \\ miroslava.barbusova@fstroj.uniza.sk \\ iveta.medvecka@fstroj.uniza.sk \\ martin.gaso@fstroj.uniza.sk
}

\begin{abstract}
Annotation: With the start of Industry 4.0, companies are increasingly focusing on one of the key factors for future production, the introduction of automation. The introduction of automation is generally considered to be an effective strategy against increasing competition and outsourcing in low cost countries. However, procurement decisions based only on the initial price are often bad decisions because they do not take into account hidden cost factors such as maintenance or energy consumption. Evaluating Total Cost of Ownership (TCO) in implementing automation is a much better alternative to calculating all the cost of ownership.
\end{abstract}

\section{Introduction}

Increasing competition in global markets, higher customer demands and shorter product lifecycles for more complex products are the reason why many organizations are under pressure to remain viable and competitive. Even companies that lead in their individual market segments need to change their strategies in order to maintain stable positions. Strategies to address these challenges are often related to increasing production efficiency and increasing technological innovation. [1, 2]

Depending on the industry, different strategies have been developed to address these problems. In particular, with the introduction of Industry 4.0, manufacturing companies are increasing the degree of automation to face global competition and outsourcing in low-cost countries. Manufacturing companies in a high-cost environment are not able to compete with low labour costs, but with the rapid and flexible production, which achieved by innovative automation. [2, 3]

A recent study indicates that purchased items make up an average $63.5 \%$ of total costs for manufacturing firms and $25.0 \%$ for non-manufacturers. Such expenditures are directly related to the organization's costs, but many discussions of strategic cost management concepts focus primarily on control of manufacturing costs, such as labour and machine time. In most organizations, the costs of purchased materials and services far outweigh internal manufacturing costs. [4, 9] 


\section{Total Cost of Ownership (TCO)}

TCO is the sum of all the apparent and all hidden costs related to the asset over the total ownership period, over the total useful life and/or over the life of the asset. [4]

Total cost of ownership (TCO) is purchasing tool and philosophy aimed at understanding the relevant cost of buying a particular good or service from a particular supplier. References to TCO and related concepts, such a life cycle cost analysis, have been in the literature for some time, but its practical application has been somewhat limited. TCO is an important tool to support strategic cost management. It is a complex approach that requires the buying firm to determine which costs it considers most relevant or significant in the acquisition, possession, use, and subsequent disposition of a good service. In addition to the price paid for the item, TCO may include the costs incurred by purchasing for order placement, research and qualification of suppliers, transportation, receiving, inspection, rejection, storage and disposal. One use of TCO analysis is to support the supplier selection and evaluation decision. Traditional approaches include selecting and retaining a supplier based on price alone, or based primarily on price, or qualitatively evaluating the supplier's performance using categorical or weighted point/matrix approaches. While the latter are preferred to a "price only" focus, such approaches tend to deemphasize the costs associated with all aspects of supplier's performance and generally disregard internal costs. Examination of such costs is strength of the TCO approach. TCO is applicable to virtually every type of purchase and includes the purchase costs associated with particular supplier. [4, 9]

When traditionally deciding how to automate, the final investment decision is often determined by the purchase price or by calculating the return on investment. However, decisions based solely on acquisition costs may prove financially weak for the company. Especially when working with advanced electronic or mechanical devices, it is more important to compare the life cycle costs of different alternatives. Many costs, such as operation, software, maintenance, training costs, or retirement costs, often accumulate while the device is running. $[6,10]$

Industrial robots and their support systems, such as conveyors or safety equipment, are high-tech products that initially cost a lot of money. Therefore, this initial price can, on the one hand, be considered as a major obstacle to the decision to purchase an industrial robotic system. On the other hand, the lowest initial price does not directly relate to the lowest cost over a period of time, that is, the cost of ownership of the automation system. Although investing in industrial robots often only calculates the purchase price and associated costs, the concept of cost of ownership is not well established. This can cause a dilemma for manufacturers and suppliers of industrial robots. Automation equipment and especially industrial robots are the future of manufacturing systems, especially in highly industrialized countries. The ability for customers to decide which products have the lowest TCO 
allows them to gain a competitive advantage, lower operating costs and financial predictability. As a result, a simple but accurate tool that allows customers to calculate cost and lifetime values would be beneficial. However, LCC and TCO are very complicated topics and many different factors need to be considered and analysed in order to produce a good overview. [7]

\subsection{Principle of TCO}

The principle of TCO is to find all the hidden costs of buying a product, the price of the product is only $25.0 \%$ of the total cost of using the product (Figure 1). For each product the hidden costs are very individual and therefore the use of TCO analysis is very demanding. Unlike traditional cost reduction and cost savings techniques that focus on all areas, TCO analysis supports strategic cost management, which means that all TCO analysis take into account the impact of purchasing decisions among the organization's costs. [4]

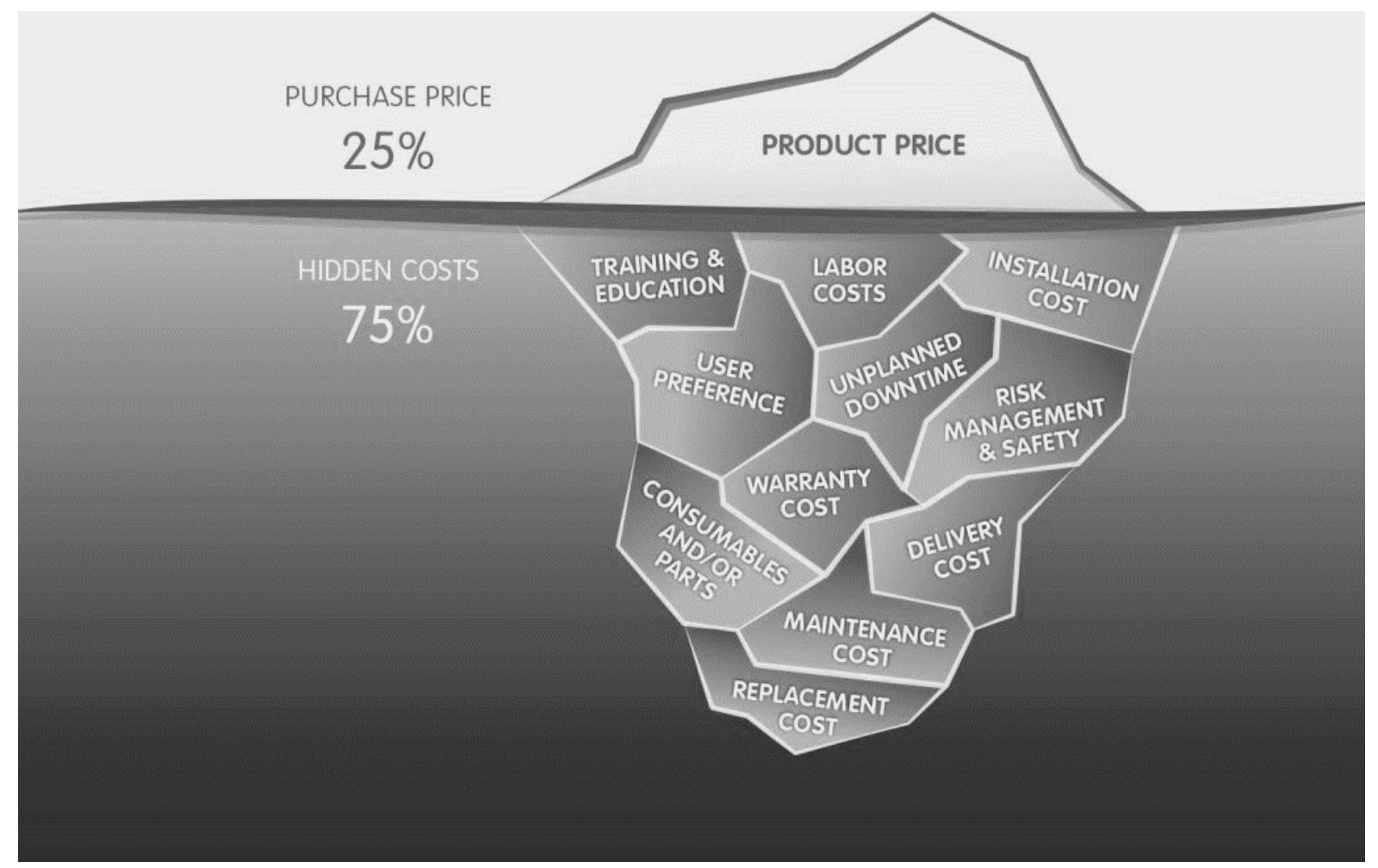

Figure 1 - Principle of TCO [3]

\subsection{Life Cycle Cost (LLC) vs. Total cost of ownership (TCO)}

The Life Cycle Cost (LCC) is an approach to cost control that aims to summarize all the cost of a product, system or service over its entire life cycle. The LCC concept therefore seeks to identify and quantify all significant costs in order to ensure the best possible choice of different alternatives. Using present value techniques, LCC often leads to more detailed results than traditional investment calculation approaches. However, LCC often also requires a lot of good and reliable data to ensure a credible result [8]. 
The product life cycle consists of two phases, each with three stages. The first three phases (needs assessment, conceptual development and detailed design) are in the acquisition phase and the last three (construction, operation as well as decommissioning and disposal) are in the operational phase. The LCC for the product increases, the longer the life cycle. [8]

Compared to LLC, the TCO takes into account the life cycle cost of the system after its purchase by an organization, as shown in the figure (Figure 2). TCO therefore provides the cost of the product from the customer's point of view. It offers a clear overview of all the costs that the system incurs for as long as it is held by customers. Examples of costs included in TCO calculations are purchase, training, energy costs, maintenance and disposal and end-of-life costs. [6]

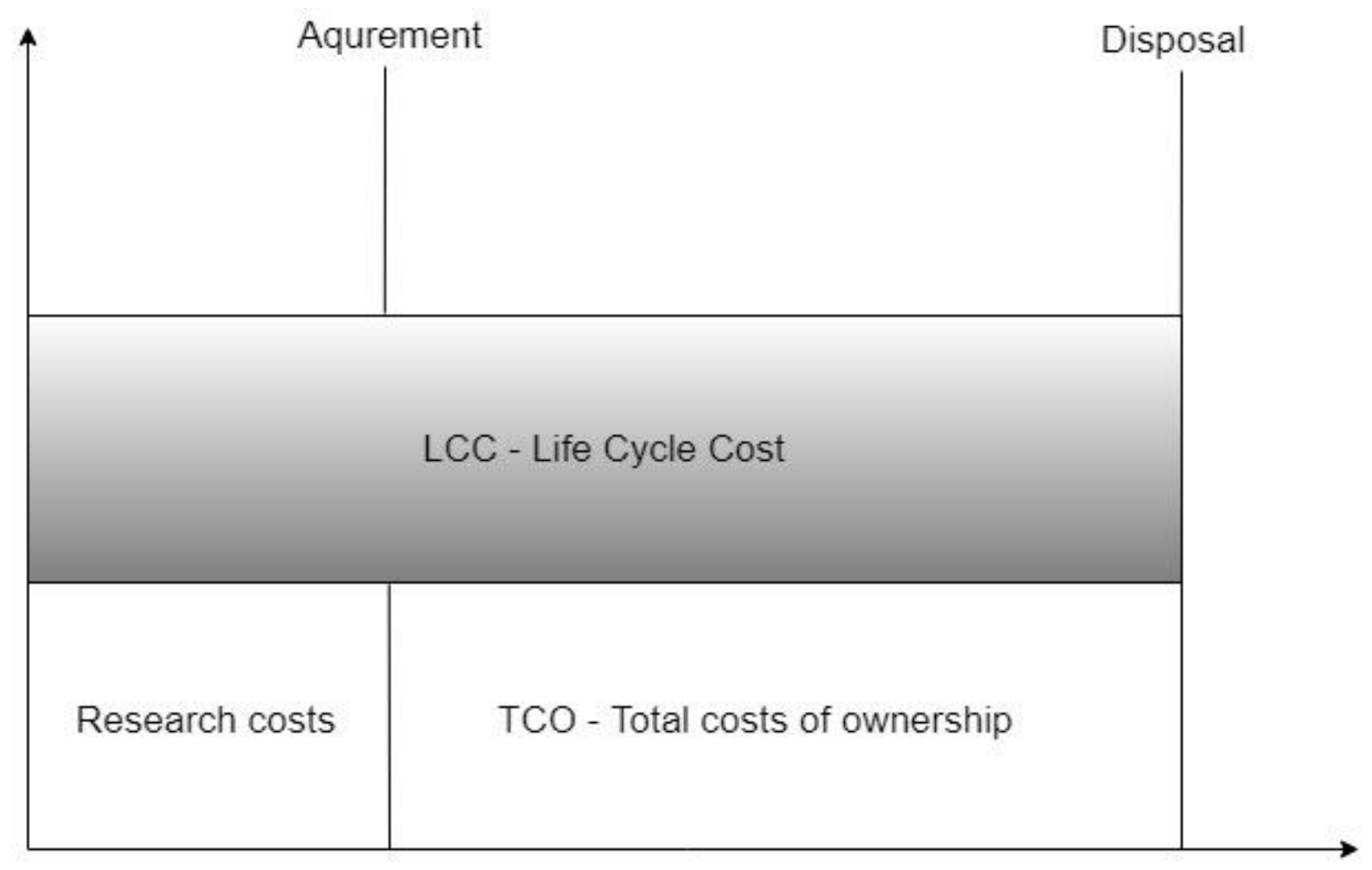

Figure 2 - The Difference between TCO and LCC [5]

The basic TCO calculations are governed by Equation (1). The total cost of ownership and operation relate to the fifth stage of the LCC cycle, i.e. construction and operation. The disposal costs refer to the last stage of the LCC cycle, i.e. to shut down and disposal.

$$
\mathrm{TCO}=\sum \mathrm{C}_{\text {ownership }}+\sum \mathrm{C}_{\text {service }}+\sum \mathrm{C}_{\text {disposal }}
$$




\section{Using TCO to select equipment for Industry $\mathbf{4 . 0}$}

When buying new industrial equipment, the price reflects one small part of a big whole. Some sources say that the amount on the price tag represents less than $10.0 \%$ of the total cost spent on a piece of equipment over its lifetime. In fact, energy costs, maintenance, and repair fees are predicted to have at least five times more relevance than the upfront cost. But few consider these factors as part of the price during their selection process. [8]

TCO must be used for full evaluation, which is an estimate of all collective expenses associated with the purchasing and operating a piece of the equipment. On the Figure 3 is seen total cost of ownership formula, where is:

I - initial cost - is the number that appears on the price tag. As previously stated, this is less than $10 \%$ of TCO.

$\mathrm{O}$ - operation - is the cost to install equipment, test the equipment, train employees to run the equipment, and the cost of energy to operate the equipment. If the equipment is complicated to use, the cost of training will increase.

M - maintenance - includes the cost of regular repairs such as cleaning, inspecting, lubricating, and adjusting the equipment to make sure it is in optimal condition. This also includes reactive maintenance when the equipment breaks down unexpectedly.

D - downtime - involves the labour costs of employees whose work is delayed, indirect labour costs from supervisors who address the issue, lost production, and lost customers from inability to meet time expectations. While you could include downtime along with the cost of maintenance, it is often so large that it warrants its own category.

$P$ - production - Two different equipment will likely have different levels of output, produce different qualities and have different environmental implications.

$\mathrm{R}$ - remaining value - has to do with the equipment's longevity. [8]

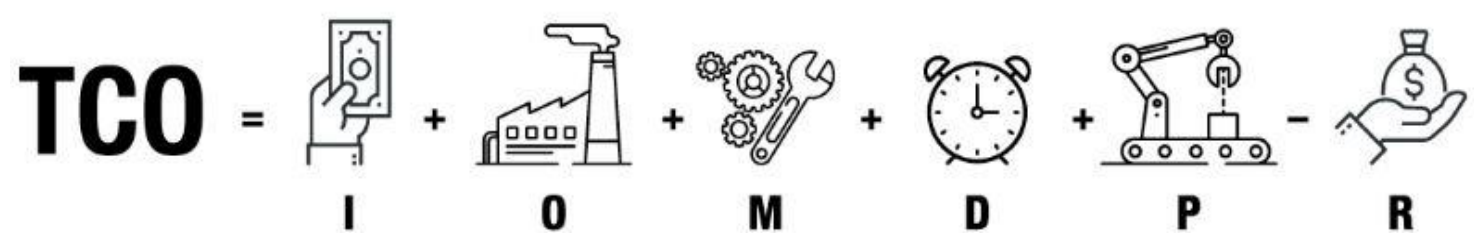

Figure 3 - Total Cost od Ownership Formula [7]

For example, we will start with three variables to compare two hypothetical equipment: E1 and E2. The variables chosen are initial cost (I), maintenance cost over 5 years (M) and the remaining value after 5 years of depreciation $(\mathrm{R})$. 
Table 1 - Calculation TCO for two industrial equipment

\begin{tabular}{|l|r|r|}
\hline & Equipment 1 (E1) & Equipment 2 (E2) \\
\hline Initial cost (I) & $10,000 €$ & $20,000 €$ \\
\hline + Maintenance (M) & $5,000 €$ & $2,000 €$ \\
\hline - Remaining value (R) & $2,000 €$ & $10,000 €$ \\
\hline = TCO & $13,000 €$ & $12,000 €$ \\
\hline
\end{tabular}

TCO E2 is lower than E1, although its initial cost was twice as much. However, the difference is only $€ 1,000$, which is a slight difference (Table 1).

Now we are adding fourth and fifth variables, estimated downtime and operation costs. We will go with an estimate of $€ 40,000$ per hour, although downtime is likely to be much more. And the operation costs for the E1 will be $€ 30,000$ and the E2 will be $€ 10,000$.

Table 2 - Calculation TCO for two industrial equipment

\begin{tabular}{|l|r|r|}
\hline & Equipment 1 (E1) & Equipment 2 (E2) \\
\hline Initial cost (I) & $10,000 €$ & $20,000 €$ \\
\hline + Operation (O) & $30,000 €$ & $10,000 €$ \\
\hline + Maintenance (M) & $5,000 €$ & $2,000 €$ \\
\hline + Downtime (D) & $(3$ hours at & $(1$ hour) \\
& $40,000 € /$ hour) & $40,000 €$ \\
\hline - Remaining value (R) & $120,000 €$ & $10,000 €$ \\
\hline = TCO & $2,000 €$ & $102,000 €$ \\
\hline
\end{tabular}

The cost of E2 industrial equipment is $€ 61,000$ lower than for $E 1$ equipment (Table 2). The price gap expands with each variable you add, giving you a clear choice for the price value. 


\section{Method}

The method of costing TCO, i.e. total cost of ownership, is used in the research. TCO is a method of evaluating cost options. The TCO expresses the full cost of the investment and its operation, taking into account not only the purchase price, but also the expenses resulting from the ownership of the valued assets.

\section{Conclusion}

The TCO approach is a concept adopted both in academia and in practice. In the business environment, however, it pays little attention. This article aims to fill this gap. The TCO calculation in the article shows that the price on the price tag is not the only cost of operating the equipment. Obviously, although the cost of procuring a single device is lower, its total cost may no longer be lower. You also need to look at the hidden costs of buying, installing, or using your device. The TCO analysis will be part of the system for evaluating the cost of innovative projects in my dissertation thesis. The advantage of using and building a TCO model is that it takes into account all cost factors, reflects the real cost of purchasing industrial robots and not just the cost of acquiring it. A properly functioning TCO model can serve as a tool for evaluating the outsourcing business and can also be used in dealing with suppliers, as it clearly shows all the hidden costs created by the supplier. But on the other hand, the TCO model is very difficult to implement because it is a complex and static system, any internal or external change must be recorded for correct results. In order for the TCO model to work properly, it is very important to know enough historical data, so there is no need for missing information about the cost of disposal.

\section{Acknowledgment}

This article was created thanks to support from the KEGA agency: KEGA $022 Z ̌ U-4 / 2018$.

\section{References}

[1] Lofving, M., Safsten, K., Winroth, M. Manufacturing strategy frameworks suitable for SMEs. In: Journal of Manufacturing Technology Management, 2014, roč. 25, č. 1, s. 7-26. ISSN 1741-038X.

[2] Horváthová, B., Bigošová, E. The ergonomic assessment - methods and technologies. In: Trendy a inovatívne prístupy v podnikových procesoch : zborník príspevkov. Technická univerzita v Košiciach, Košice, 2018, s. 1-5. ISBN 978-80-553-3210-9.

[3] Porter, M. Competitive advantage: creating and sustaining superior performance. Free Press, London, 2004. ISBN: 978-0-68-484146-5.

[4] Bhutta, K. S., Huq, F. Supplier selection problem: a comparison of the total cost of ownership and analytic hierarchy process approaches. In: Supply 
Chain Management: An International Journal, 2013, vol. 7, no. 3, p. 126135. ISSN 1359-8546.

[5] Ellram, L. M., Siferd, S. P. Total cost of ownership: A key concept in strategic cost management decisions. In: Journal of Business Logistics, 1998, vol. 19, no. 1, p. 55-69. ISSN 2158-1592.

[6] Seif, J., Rabbani, M. Component based life cycle costing in replacement decisions. In: Journal of Quality in Maintenance Engineering, 2014, vol. 20, no. 4, p. 436-452. ISSN 1355-2511.

[7] Ellram, L. M., Siferd, S. P. Purchasing: The cornerstone of the total cost of ownership concept. In: Journal of Business Logistics, 1993, vol. 14, no. 1, p. 163-184. ISSN 0735-3766.

[8] GRACO Inc. Estimating Total Cost of Ownership. [online] 2018, [cit. 201903-25].

https://www.graco.com/content/dam/graco/ipd/literature/misc/cost of owner ship/Cost of ownershipEN-A.pdf

[9] Bučková, M., Plinta, D., Gabajová, G. Smart Industry Trends. In: InvEnt 2019: Industrial Engineering - Invention for Enterprise. Wydawnictwo Akademii Techniczno-Humnistycznej w Bielsku-Białej, 2019, p. 28-32. ISBN 978-83-66249-17-2.

[10] Martinkovič, M., Mičieta, B., Biňasová, V. Human-robot cooperation in assembly process. In: InvEnt 2019: Industrial Engineering - Invention for Enterprise. Wydawnictwo Akademii Techniczno-Humnistycznej w BielskuBiałej. 2019, p. 96-100. ISBN 978-83-66249-17-2. 